\title{
Pengembangan Modul Mata Pelajaran Pendidikan Pancasila Dan Kewarganegaraan (PPKn) Untuk Siswa SMK
}

\author{
Didik Siswanto ${ }^{1}$ \\ ${ }^{1}$ Guru SMK Negeri 7 Kabupaten Sarolangun, Indonesia \\ Correspondance email: ayahesekarayu@gmail.com
}

\begin{abstract}
Abstrak: Proses pembelajaran di kelas selama ini terfokus pada pembelajaran yang terpusat pada guru (teacher center), padahal siswa sebenarnya juga memiliki potensi untuk mendapatkan pengetahuan secara mandiri. Pelaksanaan pembelajaran pada mata pelajaran Pendidikan Pancasila dan Kewarganegaraan selama ini terkesan gurunya saja yang memiliki pengetahuan yang luas sehingga ceramah dan mencatat menjadi cara dalam memberikan materi kepada peserta didik. Sementara untuk mendapatkan kompetensi yang diinginkan proses pembelajaran harus ditunjang dengan sarana pembelajaran yang memadai. Menjawab persoalan tersebut, guru sebagai fasilitator dalam pencapaian kompetensi siswa dituntut untuk kreatif mengelola pembelajaran. Salah satunya adalah dengan mencari alternatif pemecahan diantaranya dengan mengembangkan modul untuk pembelajaran. Pengembangan modul ini bertujuan untuk mendorong peserta didik untuk mencari sendiri pengetahuannya tanpa harus tergantung pada guru. Model pengembangan yang dipilih adalah berdasarkan pada model Borg dan Gall. Proses pengembangan dilakukan dengan lima langkah utama yaitu: (1) Melakukan Analisis, (2) Merancang produk awal, (3) Validasi dan revisi, (4) Uji coba lapangan sekala kecil, dan (5) Uji coba lapangan kelompok besar. Berdasarkan hasil uji coba lapangan modul mata pelajaran PPKn berkualifikasi sangat baik, artinya modul mata pelajaran PPKn menarik, sesuai kebutuhan dan karakteristik siswa. Selanjutnya dengan hasil uji coba kelompok besar yang memberikan kesimpulan bahwa dengan menggunakan modul mata pelajaran PPKn nilai siswa meningkat hal ini ditandai dengan nilai yang berada di atas nilai Kriteria Ketuntasan Minimal (KKM). Dengan adanya modul mata pelajaran PPKn untuk siswa SMK, kedepannya siswa tidak lagi tergantung pada materi yang disampaikan oleh guru di kelas, melainkan sudah mampu memperoleh pengetahuannya secara mandiri. Selanjutnya juga kedepannya pembelajaran tidak lagi terfokus pada guru melainkan sudah terfokus pada peserta didik. Kemudian untuk kesempurnaan dimasa mendatang sebaiknya uji coba penggunaan modul lebih diperluas sehingga hasilnya dapat menjadi referensi bagi guru untuk menyusun bahan ajar pembelajaran.
\end{abstract}

Kata Kunci: Pengembangan, Modul, Pendidikan Pancasila dan Kewarganegaraan

\begin{abstract}
The learning process in the clasroom has been focused on teacher centered learning even though student actually also have the potential to gain knowledge independently. The implementation of learning the Pancasila and Citizenship Education subjects has so far impressed that only teachers have extensive knowledge so that lectures and notes are a way of providing material to students. Meanwhile, to get the desired competence, the learning process must be supported by adequate learning facilities. Answering this problem, teachers as facilitators in achieving student competence are required to creatively manage learning. One way is to find alternative solutions, including by developing Modules for learning. The development of this module aims to encourage students to seek their own knowledge without having to depend on the teacher. The development model chosen is based on the Borg and Gall models. The development process is carried out in five main steps, namely: (1) Conducting analysis, (2) Designing the initial product, (3) Validating and revising, (4) Small-scale field trials, and (5) Large group field trials. Based on the results of field trials, the PPKn subject modules are very well qualified, meaning that the PPKn subject modules are interesting, according to the needs and characteristics of students. Furthermore, with the results of the large group trial which concluded that by using the PPKn subject module, student scores increased, this was indicated by the value that was above the value of the minimum completeness criteria. With the existence of the PPKn subject module for vocational students, in the future students will no longer depend on the material presented by the teacher in class, but are able to obtain their knowledge independently. Furthermore, in the future learning is no longer focused on teachers but is already focused on students. Then for perfection in the future it is better if the trial use of the module is more expanded so that the results can be a reference for teachers to prepare learning teaching materials.
\end{abstract}

Key words : Development, Modules, Pancasila and Citizenship Education

\section{PENDAHULUAN}

Pendidikan merupakan komunikasi terorganisasi dan berkelanjutan yang dirancang untuk menumbuhkan kegiatan belajar pada diri siswa. Siswa mampu mengembangkan kemampuan menemukan, mengelola, dan mengevaluasi informasi dan pengetahuan untuk memecahkan masalah pada dunia yang nyata dan ikut serta aktif 
dalam kegiatan bermasyarakat di lingkungannya. Untuk itu diperlukan proses pembelajaran yang efektif dan efisien yang menjadikan siswa menyerap informasi dan pengetahuan serta teknologi yang dipelajarinya sebagai bagian dari dirinya.

Keberhasilan seorang guru memberikan pembelajaran yang efektif ditandai dengan adanya proses belajar pada siswa. Siswa mampu membangun pengetahuannya sendiri melalui proses pembelajaran tersebut. Pembelajaran hendaknya menempatkan siswa sebagai pusat pembelajaran. Peran guru hanya sebagai fasilitator, sedangkan proses belajar dijalani sendiri oleh siswa, sehingga guru harus mampu mendesain pembelajaran dengan baik agar terjadi interaksi antara guru dan siswa, misalnya dengan cara mendesain bahan ajar yang sesuai dengan kebutuhan dan karakter siswa baik pembelajaran itu dilaksanakan secara berkelompok maupun individu.

Salah satu kompetensi yang perlu dimiliki seorang guru dalam melaksanakan tugasnya adalah mengembangkan bahan ajar. Pengembangan bahan ajar penting dilakukan guru agar pembelajaran lebih efektif, efisien, dan tidak melenceng dari kompetensi yang ingin dicapainya. Kompetensi mengembangkan bahan ajar idealnya telah dikuasai guru secara baik, namun pada kenyataannya masih banyak guru yang belum menguasainya, sehingga dalam melakukan proses pembelajaran masih banyak yang bersifat konvensional. Dampak dari pembelajaran konvensional ini antara lain aktivitas guru lebih dominan dan sebaliknya siswa kurang aktif karena lebih cenderung menjadi pendengar. Disamping itu pembelajaran yang dilakukannya juga kurang menarik karena pembelajaran kurang variatif. Berkenaan dengan pemilihan bahan ajar ini, secara umum masalah dimaksud meliputi cara penentuan jenis materi, kedalaman, ruang lingkup, urutan penyajian, perlakuan (treatment) terhadap materi pembelajaran. Selanjutnya, pengembangan bahan ajar harus dapat menjawab atau memecahkan masalah ataupun kesulitan dalam belajar. Terdapat sejumlah materi pembelajaran yang seringkali siswa sulit untuk memahaminya ataupun guru sulit untuk menjelaskannya. Kesulitan tersebut dapat saja terjadi karena materi tersebut abstrak, rumit, asing, dsb. Untuk mengatasi kesulitan ini maka perlu dikembangkan bahan ajar yang tepat.

Secara umum pembelajaran selama ini baik di tingkat sekolah dasar hingga sekolah menengah atas selalu monoton, pembelajaran hanya terfokus pada guru (teacher centered), sehingga peserta didik menjadi jenuh, bosan dan bahkan pada akhirnya peserta didik menjadi tidak tertarik pada mata pelajaran tersebut. Padahal seharusnya pembelajaran lebih ditujukan pada peserta didik (student centerded) sehingga diperlukan adanya fasilitas pembelajaran yang mampu mendorong peserta didik belajar secara mandiri. Bahan ajar yang dimaksud dalam hal ini adalah modul. Modul merupakan bahan ajar cetak yang dirancang untuk dapat dipelajari secara mandiri oleh peserta pembelajaran. Modul disebut juga media untuk belajar mandiri karena di dalamnya telah dilengkapi petunjuk untuk belajar mandiri. Penggunaan modul dalam kegiatan pembelajaran diharapkan dapat mempermudah siswa dalam memahami suatu materi yang dilengkapi dengan gambar yang menarik, gaya penulisan yang komunikatif yang diharapkan akan menambah motivasi dan minat baca siswa.

Sistem pembelajaran dengan menggunakan modul akan membuat pembelajaran menjadi efisien, efektif dan relevan. Dibandingkan dengan pembelajaran konvensional yang cenderung bersifat klasikal dan dilaksanakan tatap muka. Pembelajaran menggunakan modul memudahkan peserta didik untuk memahami materi pembelajaran. Pembelajaran pada mata pelajaran Pendidikan Pancasila dan Kewarganegaraan selama ini juga dianggap pembelajaran yang menjemukan, guru yang mengajarkan terkesan pandai sendiri tanpa memperhatikan potensi-potensi yang dimiliki oleh siswa. Pembelajaran pada mata pelajaran PPKn banyak didominasi oleh gurunya karena siswa hanya diberi ceramah dan didikte serta hanya menggunakan buku-buku yang telah usang, kajian-kajian yang sudah tidak relevan dengan perkembangan zaman.

Mengingat mata pelajaran PPKn merupakan mata pelajaran yang didalamnya juga terkait perilaku maka penggunaan modul dalam pembelajaran akan menciptakan pembelajaran yang menarik karena peserta didik bisa mengkaitkan teori yang ada di dalam modul dengan konteks masalah yang ada dimasyarakat melalui proses pemodelan. SMK merupakan salah satu sekolah yang tidak hanya memberikan konsep teori kepada peserta didik, melainkan juga membekali peserta didik dengan keterampilan yang menyesuaikan dengan kebutuhan dunia usaha dan dunia industri. Dengan menggunakan modul dalam memberikan materi pembelajaran, peserta didik di SMK akan mampu belajar secara mandiri.

Penggunaan berbagai sarana dan sumber belajar yang memadai sangat penting dan sangat menunjang proses pembelajaran bagi peserta didik. Berbagai sumber belajar dapat dimanfaatkan antara lain laboratorium, media, alat dan bahan, pesan dan teknik guru, konsultan dan teknisi. Sumber belajar merupakan sesuatu hal yang memiliki potensi untuk mendukung kegiatan pembelajaran. Belajar tidak hanya dilaksanakan di kelas, melainkan dapat dilaksanakan di luar kelas secara mandiri. Tujuan pengembangan modul mata pelajaran PPKn adalah a). Untuk menghasilkan produk modul bahan ajar ditingkat satuan pendidikan yaitu Sekolah Menengah Kejuruan, b). Untuk memudahkan guru dan siswa dalam mencapai kompetensi yang diamanatkan dalam Kurikulum. 


\section{LANDASAN TEORI}

Modul merupakan suatu unit program pengajaran yang disusun dalam bentuk tertentu untuk keperluan belajar. Menurut makna istilah asalnya modul adalah alat ukur yang lengkap, merupakan unit yang dapat berfungsi secara mandiri, terpisah, tetapi juga dapat berfungsi sebagai kesatuan dari seluruh unit lainnya (Nana Sudjana dan Ahmad Rivai, 2007:132). Sedangkan menurut Jerrold E, Kemp 1978 seperti yang dikutip oleh Made Wena (2010: 231) modul diartikan sebagai paket pembelajaran mandiri berisi satu topik atau unit materi pelajaran dan memerlukan waktu belajar beberapa jauh untuk satu minggu. Modul menurut Direktorat Tenaga Kependidikan seperti yang dikemukakan oleh Eliyawati (2015: 44) adalah salah satu bentuk bahan ajar yang dikemas secara utuh dan sistematis, didalamnya memuat seperangkat pengalaman belajar yang terencana dan didesain untuk membantu peserta didik menguasai tujuan belajar yang spesifik.

Modul berfungsi sebagai sarana belajar yang bersifat mandiri, sehingga peserta didik dapat belajar sesuai dengan kecepatan masing-masing. Sedangkan menurut Sabri (2007) modul merupakan kesatuan unit yang lengkap terdiri atas rangkaian kegiatan belajar yang disusun untuk membantu siswa dalam mencapai tujuan yang telah dirumuskan. Modul merupakan paket kurikulum yang disediakan untuk dapat digunakan oleh siswa belajar sendiri sehingga tanpa kehadiran guru siswa dapat belajar mandiri (Eliyawati, 2015: 45)

Selanjutnya menurut Badan Penelitian dan Pengembangan Pendidikan dan Kebudayaan, pengertian modul adalah satu unit program belajar mengajar terkecil yang secara rinci menggariskan hal-hal sebagai berikut: (1) tujuan instruksional yang akan dicapai; (2) topik yang akan dijadikan pangkal proses belajar mengajar; (3) pokok-pokok yang akan dipelajari; (4) kedudukan dan fungsi modul dalam kesatuan program yang lebih luas; (5) peranan guru dalam proses belajar mengajar; (6) alat dan sumber belajar yang dipergunakan; (7) kegiatan belajar yang harus dilakukan dan dihayati siswa secara berurutan; (8) lembaran kerja yang harus diisi oleh siswa; (9) program evaluasi yang akan dilaksanakan (Made Wena, 2010: 23) .

Kemudian menurut Russel modul adalah suatu paket pembelajaran yang berisi satu unit konsep tunggal, sedangkan menurut Houston dan Howson modul diartikan sebagai seperangkat aktivitas yang bertujuan mempermudah siswa untuk mencapai seperangkat tujuan pembelajaran. Sehingga dapat dikatakan bahwa modul merupakan seperangkat pembelajaran yang di dalamnya terdapat berbagai kumpulan konsep yang bertujuan membantu siswa dalam mencapai kemampuannya (Made Wena, 2010: 230)

Secara umum, tujuan Pendidikan Pancasila dan Kewarganegaraan harus ajeg dan mendukung keberhasilan pencapaian tujuan Pendidikan Nasional sebagaimana ditetapkan dalam Undang-Undang Nomor : 20 Tahun 2003 pasal 3 yaitu: Pendidikan nasional berfungsi mengembangkan kemampuan dan membentuk watak serta peradaban bangsa yang bermartabat dalam rangka mencerdaskan kehidupan bangsa, bertujuan untuk berkembangnya potensi peserta didik agar menjadi manusia yang beriman dan bertakwa kepada Tuhan Yang Maha Esa, berakhlak mulia, sehat, berilmu, cakap, kreatif, mandiri, dan menjadi warga negara yang demokratis serta bertanggung jawab. Sedangkan secara khusus, Pendidikan Pancasila dan Kewarganegaraan memiliki tujuan sebagai berikut : "Pendidikan Kewarganegaraan dimaksudkan untuk membentuk peserta didik menjadi manusia yang memiliki rasa kebangsaan dan cinta tanah air". (Penjelasan Undang-Undang No. 20 Tahun 2003 pasal 37 ayat 1).

Sekolah Menengah Kejuruan (SMK) sebagai bentuk satuan pendidikan kejuruan sebagaimana ditegaskan dalam penjelasan pasal 15 Undang-Undang Sistem Pendidikan Nasional merupakan pendidikan menengah yang menyiapkan peserta didik terutama untuk bekerja dalam bidang tertentu. Tujuan umum sekolah menengah kejuruan adalah:

a. Menyiapkan peserta didik agar dapat menjalani kehidupan secara layak

b. Meningkatkan keimanan dan ketakwaan peserta didik

c. Menyiapkan peserta didik agar menjadi warga negara yang mandiri dan bertanggung jawab

d. Menyiapkan peserta didik agar memahami dan menghargai keanekaragaman budaya bangsa Indonesia

e. Menyiapkan peserta didik agar dapat menerapkan dan memelihara hidup sehat, memiliki wawasan lingkungan, pengetahuan, dan seni

\section{METODE PENELITIAN}

Penelitian ini menggunakan metode Research and Development $(\mathrm{R} \& \mathrm{D})$ yaitu suatu penelitian yang digunakan untuk menghasilkan produk tertentu dan menguji keefektifan produk tertentu. suatu proses atau langkah-langkah untuk mengembangkan suatu produk baru atau menyempurnakan produk yang telah ada, yang dapat dipertanggung jawabkan. Sukmadinata (2008:164) mengemukakan bahwa untuk mendapatkan hasil produk tertentu digunakan penelitian yang bersifat analisis kebutuhan, dan untuk menguji keefektifan produk supaya dapat berfungsi di masyarakat luas diperlukan penelitian untuk menguji keefektifan produk tersebut. 
Untuk pengembangan modul mata pelajaran PPKn model yang dipilih adalah model pengembangan prosedural yang menunjukkan langkah-langkah yang harus diikuti untuk menghasilkan produk. Sedangkan metode yang digunakan adalah metode penelitian dan pengembangan atau Research and Development (R\&D), metode ini digunakan untuk menghasilkan produk dan menguji keefektifan produk tersebut (Sugiono 2009:297). Penelitian pengembangan ini sebagai suatu pengkajian sistematis terhadap proses analisis, perancangan, pengembangan, evaluasi, dan penerapan dari produk modul mata pelajaran PPKn yang harus memenuhi kriteria validitas dan efektivitas. Model pengembangan yang dipilih adalah model Borg dan Gall.

\section{HASIL DAN PEMBAHASAN}

Adapun hasil dari penilaian ahli materi adalah sebagai berikut: Pada komponen kelengkapan materi ahli materi menyatakan bahwa modul mata pelajaran PPKn sudah lengkap, maksudnya adalah bahwa materi yang terdapat dalam modul sudah sesuai dengan Kompetensi Inti dan Kompetensi Dasar pada mata pelajaran PPKn seperti yang terdapat dalam Kurikulum 2013. Selanjutnya pada komponen keluasan materi dinyatakan oleh ahli materi, bahwa modul mata pelajaran PPKn sudah cukup luas, maksudnya adalah materi yang terdapat dalam modul merupakan penjabaran yang mendukung pencapaian semua kompetensi dasar.

Pada komponen kedalaman materi, modul mata pelajaran PPKn dinyatakan oleh ahli materi sudah cukup dalam, artinya bahwa materi yang disajikan dalam modul mata pelajaran PPKn dimulai dari pengenalan konsep, definisi, prosedur, tampilan output, contoh, kasus, latihan, sampai dengan interaksi antar konsep sesuai dengan tingkat pendidikan pada satuan sekolah menengah kejuruan. Sedangkan untuk komponen keakuratan definisi pada komponen kedalaman materi, modul mata pelajaran PPKn dinyatakan oleh ahli materi sudah cukup mendalam, artinya bahwa materi yang disajikan dalam modul mata pelajaran PPKn dimulai dari pengenalan konsep, definisi, prosedur, sudah sesuai dengan materi pada tingkat satuan sekolah menengah kejuruan. Kemudian pada komponen keakuratan konsep dan definisi dinyatakan oleh ahli materi bahwa modul mata pelajaran PPKn perlu dibuatkan sintesis setelah mengutip pendapat ahli, sehingga dapat membawa peserta didik untuk memahami dan definisi hukum, sistem hukum, dan sanksi hukum.

Selanjutnya pada komponen kesesuaian perkembangan intelektual peserta didik, modul mata pelajaran PPKn dinyatakan oleh ahli materi sudah sesuai dengan perkembangan intelektual peserta didik, artinya bahasa yang dipergunakan ataupun materi yang terdapat dalam modul sesuai dengan perkembangan keilmuan peserta didik pada usia anak sekolah di SMK, sedangkan pada komponen kesesuaian dengan tingkat perkembangan emosional peserta didik dinyatakan oleh ahli materi bahwa modul sudah sangat sesuai, artinya modul mata pelajaran PPKn bahasa yang dipergunakan ataupun materi yang terdapat dalam modul sudah sesuai dengan tingkat perkembangan emosional peserta didik.

Selanjutnya pada komponen keruntutan dan keterpaduan antar kegiatan belajar, modul dinyatakan oleh ahli materi secara umum sudah runtut terkecuali pada kompetensi dasar pengertian sistem, sistem hukum, dan hukum seharusnya materi dimulai dari penjelasan tentang sistem, pengertian hukum dan pengertian sistem hukum. Sedangkan pada komponen keruntutan dan keterpaduan antar paragraf modul dinytakan oleh ahli materi, bahwa dalam satu paragraf setidaknya ada satu pokok pikiran, jangan terlalu banyak pokok pikiran karena akan membingungkan peserta didik dalam memahami modul. Pada komponen konsistensi penggunaan istilah modul mata pelajaran PPKn dinyatakan oleh ahli materi sudah cukup konsisten, artinya penggunaan istilah yang menggambarkan suatu konsep harus konsisten antar-bagian dalam modul, selanjutnya pada komponen konsistensi penggunaan simbol modul mata pelajaran PPKn dinyatakan oleh ahli materi sudah cukup konsisten, artinya penggambaran simbol atau ikon konsisten antar-bagian dalam modul.

Pada komponen kesesuaian penilaian dengan tujuan pembelajaran, modul mata pelajaran PPKn dinyatakan sudah cukup sesuai, artinya penilaian yang terdapat dalam modul mata pelajaran sesuai dengan tujuan pembelajaran pada tiap-tiap kegiatan pembelajaran sehingga memudahkan peserta didik dalam memahami modul, selanjutnya pada komponen kesesuaian penilaian dengan materi pada modul, ahli materi menyatakan modul sudah sesuai, artinya penilaian yang terdapat dalam modul tidak menyimpang dari materi yang terdapat pada tiap-tiap kegiatan pembelajaran pada modul, serta pada komponen kesesuaian jenis-jenis dan bentuk penilaian aspek kognitif modul mata pelajaran PPKn dinyatakan oleh ahli materi sudah sesuai artinya penilaian aspek kognitif sudah sesuai dengan tingkatan-tingkatan penilaian pada aspek kognitif.

Berdasarkan saran dan komentar dari ahli materi maka disimpulkan modul layak untuk diujicobakan dengan tetap melakukan perbaikan-perbaikan atau revisi sehingga modul layak untuk diujicobakan. Hasil dari penilaian yang dilakukan oleh ahli desain pembelajaran adalah sebagai berikut: Pada komponen tampilan warna pada cover modul, ahli desain menyatakan modul mata pelajaran PPKn tidak menarik jika melihat penampilan warna pada cover modul, desain modul tidak menarik, seharusnya dicari back ground warna yang menarik serta tidak sekedar menempel gambar. Kemudian pada komponen tampilan warna pada gambar yang ditampilkan pada modul, ahli desain 
menyatakan modul mata pelajaran PPKn sebaiknya pada modul memiliki warna utama sehingga peserta didik menjadi tertarik untuk membaca dan menggunakannya.

Pada komponen ketepatan penempatan gambar, modul mata pelajaran PPKn dinyatakan oleh ahli desain yaitu gambar pada modul sudah bagus, namun dalam penempatannya masih monoton sehingga sebaiknya modul dalam hal penempatan gambar divariasikan dari sisi ukuran dan posisi. Kemudian pada komponen bahasa yang digunakan baik dan benar ahli desain menyatakan modul sudah menggunakan bahasa yang baik dan benar, artinya bahasa yang digunakan dalam modul sudah mengikuti kaidah-kaidah kebahasaan yang ada menurut ejaan yang disempurnakan serta mudah dipahami oleh peserta didik. Pada komponen bahasa yang digunakan mudah dipahami oleh peserta didik dinyatakan oleh ahli desain bahwa bahasa sudah sesuai artinya bahasa yang digunakan dalam modul mudah dipahami oleh peserta didik sehingga peserta didik dengan mudah memahami materi yang terdapat dalam modul. Kemudian pada komponen kejelasan tulisan dan pengetikan, ahli desain menyatakan modul sudah sangat sesuai, artinya tulisan dan pengetikan modul telah mengikuti kaidah-kaidah penulisan yang benar.

Pada komponen jenis ukuran dan bentuk huruf, modul mata pelajaran PPKn dinyatakan oleh ahli desain sudah sesuai dengan kaidah penulisan modul yang mana jenis huruf dan bentuk huruf tersebut memudahkan peserta didik dalam membaca dan memahami modul tersebut. Kemudian pada komponen ketepatan penulisan modul ahli desain menyatakan bahwa modul mata pelajaran PPKn sudah sesuai, artinya penulisan modul sudah sesuai denga kaidah penulisan modul yang benar dan baik. Pada komponen kegiatan pembelajaran, ahli desain menyatakan modul mata pelajaran PPKn sudah sesuai, artinya kegiatan pembelajaran yang ada pada modul dirancang guna memudahkan peserta didik dalam memahami modul. Kemudian pada komponen ketepatan penulisan judul ahli desain menyatakan modul mata pelajaran PPKn sudah cukup sesuai, artinya penulisan judul disesuaikan dengan kompetensi dasar yang ada pada mata pelajaran PPKn pada materi sistem hukum dan peradilan nasional.

Pada komponen ketepatan petunjuk penggunaan modul, ahli desain menyatakan bahwa modul mata pelajaran PPKn dalam hal penggunaan petunjuk penggunaan modul sebaiknya ditambahkan misalnya lakukan evaluasi sebelum pindah ke modul selanjutnya. Kemudian pada komponen ketepatan rumusan tujuan pembelajaran, dinyatakan oleh ahli desain bahwa tujuan pembelajaran tidak hanya berkaitan dengan kognitif saja tapi juga terkait dengan sikap dan keterampilan.

Pada komponen ketepatan penataan paragraf, modul mata pelajaran PPKn dinyatakan sudah cukup tepat, artinya paragraf sudah tertata dengan baik dan benar, sehingga mudah dipahami oleh peserta didik. Selanjutnya pada komponen konsistensi kegiatan pembelajaran dengan tujuan pembelajaran dinyatakan oleh ahli desain sudah cukup konsisten, artinya kegiatan pembelajaran dengan tujuan pembelajaran saling terkait karena akan memudahkan peserta didik dalam memahami modul tersebut. Pada komponen relevansi kegiatan pembelajaran dengan belajar mandiri peserta didik modul dinyatakan oleh ahli desain sudah cukup sesuai, artinya modul adalah dalam rangka untuk menjadikan peserta didik belajar mandiri dan tidak tergantung pada guru dalam hal menerima pengetahuannya, sedangkan pada komponen ketepatan modul dengan karakteristik peserta didik ahli desain menyatakan modul sudah cukup sesuai, artinya modul disusun sesuai dengan tingkat kemampuan peserta didik pada jenjang sekolah menengah kejuruan yakni pada usia 12 sampai dengan 18 tahun.

Pada komponen konsistensi isi rangkuman dengan tujuan pembelajaran, modul mata pelajaran PPKn dinyatakan oleh ahli desain sudah cukup konsisten, artinya isi rangkuman sinkron dengan tujuan pembelajaran, sehingga peserta didik dapat memahami garis besar dari materi yang terdapat dalam modul mata pelajaran PPKn. Kemudian pada komponen kesesuaian latihan soal dengan tujuan pembelajaran, modul dinyatakan oleh ahli desain sudah cukup sesuai, artinya latihan soal yang terdapat dalam modul disesuaikan dengan tujuan pembelajaran yang ingin dicapai oleh peserta didik. Pada komponen kesesuaian tes formatif dengan tujuan pembelajaran, modul dinyatakan oleh ahli desain sudah sesuai, artinya tes formatif yang disajikan didasarkan pada rumusan tujuan pembelajaran, selanjutnya pada komponen kesesuaian tes sumatif dengan tujuan pembelajaran dinyatakan bahwa modul sudah sesuai artinya tes sumatif yang disajikan juga didasarkan pada rumusan tujuan pembelajaran yang terdapat pada bagian awal modul serta pada komponen umpan balik yang terdapat pada modul oleh ahli desain dinyatakan sebaiknya pada modul disediakan link pada sumber belajar yang lain sehingga peserta didik dapat mencari informasi lebih detail lagi.

Pada akhir kesimpulannya ahli desain memberikan kesimpulan bahwa modul mata pelajaran PPKn pada materi sistem hukum dan peradilan nasional berada pada kualifikasi cukup baik dan tetap diberikan koreksi untuk dilakukan perbaikan-perbaikan supaya layak untuk diujicobakan. Sasaran Uji coba modul mata pelajaran PPKn adalah calon pengguna produk pengembangan, yaitu siswa kelas X. Uji coba ini bertujuan untuk mengetahui keterlaksanaan, manfaat, mengetahui efektifitas belajar menggunakan Modul serta efektifitas penggunaan modul mata pelajaran PPKn. Uji coba pertama dilakukan kepada peserta didik dalam kelompok kecil, yakni sebanyak enam siswa. Proses uji coba kelompok kecil ini dilakukan dengan memberika pertanyaan berupa angket tertutup. Angket tertutup untuk mendapatkan informasi berupa data kuantitatif. Uji coba ini dilakukan untuk keterlaksanaan dan manfaat serta 
efektifitas penggunaan modul mata pelajaran PPKn. Uji coba kedua dilaksanakan dalam kelompok siswa yang lebih besar (satu kelas) yakni sebanyak 36 siswa.

Uji coba dilakukan untuk mengetahui efektifitas belajar menggunakan Modul. Dalam uji coba kelompok besar ini modul mata pelajaran PPKn digunakan dalam lima kali pertemuan (lima kegiatan pembelajaran). Uji coba dalam kelompok kecil, yakni sebanyak 6 (enam) siswa. Proses uji coba kelompok kecil ini dilakukan dengan memberika pertanyaan berupa angket tertutup. Angket tertutup untuk mendapatkan informasi berupa data kuantitatif. Jika dituliskan prosentase hasilnya adalah sebagai berikut: responden 1 memberikan skor $80 \%$, responden 2 memberikan skor $80 \%$, responden 3 memberikan skor $78 \%$, responden 4 memberikan skor $78 \%$, responden 5 memberikan skor $82 \%$ dan responden 6 memberikan skor $88 \%$. Dengan demikian rata-rata prosentase skor responden adalah $81 \%$, yang artinya modul ini mempunyai kualifikasi sangat baik.

Uji coba kelompok besar dilakukan sebanyak 5 kali (lima kegiatan pembelajaran). Pada saat uji coba kelompok besar pertama dilakukan dengan memberikan soal sebanyak 10 pada kegiatan pembelajaran pertama yang membahas materi tentang sistem hukum dan peradilan nasional. Diperoleh rata-rata nilai sebelum menggunakan modul adalah 55,5 sedangkan setelah menggunakan modul diperoleh rata-rata nilai sebesar 77,7 artinya ada peningkatan sebesar 40 persen setelah peserta didik menggunakan modul pada kegiatan pembelajaran mengenai sistem hukum dan peradilan nasional. Kemudian dilakukan kembali uji lapangan dengan materi pada kegiatan pembelajaran kedua yang membahas tentang peranan lembaga-lembaga peradilan. Diperoleh nilai rata-rata sebelum menggunakan modul sebesar 45,5 sedangkan setelah menggunakan modul diperoleh rata-rata nilai sebesar 77,2 artinya terdapat peningkatan sebesar 69,7 persen setelah peserta didik menggunakan modul pada kegiatan pembelajaran mengenai peranan lembaga-lembaga peradilan.

Selanjutnya pada uji lapangan yang ketiga dengan materi pada kegiatan pembelajaran tentang tingkatan peranan, dan fungsi lembaga peradilan. Diperoleh nilai rata-rata sebelum menggunakan modul sebesar 55,3 sedangkan setelah menggunakan modul diperoleh nilai rata-rata sebesar 76,4 artinya terdapat peningkatan sebesar 38,2 persen setelah peserta didik menggunakan modul pada kegiatan pemebelajaran mengenai tingkatan peranan, dan fungsi lembaga peradilan.

Pada uji lapangan yang keempat dengan materi pada kegiatan pembelajaran tentang menganalisis upaya pemberantasan korupsi di Indonesia sebelum menggunakan modul diperoleh rata-rata nilai sebesar 49, 2, sedangkan setelah menggunakan modul diperoleh nilai rata-rata sebesar 79,2 artinya terdapat peningkatan nilai rata-rata sebesar 60 persen. Pada uji lapangan tahap terakhir atau tahap kelima pada kegiatan pembelajaran tentang menampilkan peran serta dalam upaya pemberantasan korupsi diperoleh nilai rata-rata sebelum menggunakan modul sebesar 65, sedangkan setelah menggunakan modul diperoleh rata-rata nilai sebesar 85, artinya terdapat peningkatan sebesar 30 persen. Sehingga dapat disimpulkan bahwa modul mata pelajaran PPKn dapat meningkatkan efektifitas pembelajaran bagi siswa yang ditandai dengan meningkatnya nilai peserta didik di atas nilai Kriteria Ketuntasan Minimal yaitu 70.

\section{SIMPULAN}

Modul mata pelajaran Pendidikan Pancasila dan Kewarganegaran untuk siswa SMK telah dikembangkan melalui langkah-langkah yaitu analisis kebutuhan awal, penyusunan desain, pembuatan produk, validasi ahli dan uji coba lapangan. Produk modul mata pelajaran PPKn menarik dan sesuai dengan karakteristik siswa, hal ini ditandai dengan hasil $81 \%$ modul berkualifikasi sangat baik, ditinjau dari adanya peta kedudukan modul, petunjuk penggunaan modul, teks pada modul, gambar yang terdapat pada modul, meningkatnya daya tarik belajar, daya belajar secara mandiri, penggunaan bahasa, relevansi materi dengan kondisi kekinian, sehingga modul mata pelajaran PPKn dapat dinyatakan menarik, sesuai dengan karakteristik siswa. Produk modul Mata Pelajaran PPKn dapat meningkatkan nilai siswa karena dengan menggunakan modul hasil dari nilai rata-rata yang diperoleh siswa yaitu 85 dibandingkan dengan tidak menggunakan modul, sehingga nilai mata pelajaran PKPn meningkat secara prosentase yakni nilai diatas Kriteria Ketuntasan Minimal yaitu 70.

\section{DAFTAR PUSTAKA}

Borg,Walter R and Gall, Meridith. Damien 2003. Educational Research an Introduction. New York \& London: Longman

Eliyawati. Pengembangan Modul Kinematika Gerak Dengan Analisis Vektor Pada SMA Kelas XI. Tesis, Program Pascasarjana Universitas Lampung. Lampung. 2015.

Sudjana, Nana dan Rivai, Ahmad. 2007. Teknologi Pengajaran. Bandung: Sinar Baru Algensindo

Sugiono. 2009. Metode Penelitian Pendidikan Pendekatan kuantitatif, kualitatif dan R\&D. Bandung: ALFABETA.

Sukmadinata, S. N. 2008. Metode Penelitian Pendidikan. Bandung: PT.Remaja Rosdakarya.

Wena Made. 2010. Strategi Pembelajaran Inovatif Kontemporer. Jakarta: Bumi Aksara 